\title{
AN ANALYSIS OF THE DECISIVE CRITERIA IN FORMWORK SELECTION PROBLEM
}

\section{A. KRAWCZYŃSKA - PIECHNA ${ }^{1}$}

\begin{abstract}
The present paper concerns a problem of decisive criteria and their order in formwork selection problem. As the factors affecting the choice of exact formwork system have been often discussed in literature, their importance has not been distinctly formulated yet, what hampers aiding formwork selection with MCDA methods that require criteria weights (eg.: SAW, TOPSIS etc.). Therefore, author ran a survey - the decisive criteria were recognized and verified within polls send to various contractors. An analysis of survey results including criteria ordering is a subject of the present elaboration.
\end{abstract}

Keywords: formwork selection, selection criteria, decision criteria ordering

\section{INTRODUCTION}

Formwork is the largest single cost item in cast-in place reinforced concrete structure and can be estimated as $30-40 \%$ of the cost of the concrete skeleton. Therefore, any opportunity for cost saving and reducing the cost of formwork system, should be considered. However, as Ignatowski mentions in [6], the market offers so many formwork solutions, that the contractor usually follows only the price when leasing formwork elements. At the same time he can make technological and organizing mistakes, such as for example: leasing inadequate number of formwork elements with reference to concrete structure and its complexity, paying too little attention to expensive safety equipment, choosing and applying heavy systems, where light-weight elements could be used, using too many couplers, ties (what increases labour productivity), using wall and column formwork system inadequate for concrete pressure growth, underestimating the usefulness of girder wall formwork

\footnotetext{
${ }^{1}$ MSc. Civ. Eng., Warsaw University of Technology, Faculty of Civil Engineering, Mechanics and Petrochemistry, 17 Lukasiewicza St., 09-402 Płock, Poland, e-mail: krawczynska@pw.plock.pl
} 
and high-quality plywood in case of exposed concrete or using inadequate cheaper slab formwork systems (what increases labour productivity). It's easy to deduce, that having profound knowledge on formwork systems and choosing an appropriate system to perform concrete works brings about: reduction of labour costs, improving the quality and safety of produced concrete, achieving faster work cycles. This is why formwork selection problem has been widely discussed since early 90's until now by various researchers all over the world, mainly in: the United States and Canada (Hanna, Willenbrock, Sanvido [4,5], Kamarthi [8]), United Kingdom (Proverbs, Holt, Olomolaiye [12]), Middle East (Elbeltagi, Abdel-Razek [3]) and Far East (Kang, Shin [9], Tam [16]) and others. This is a logical result of a dynamic development of high-rise building in those countries combined with a progress of knowledge-based techniques supporting decision-making for industry. In Poland, the problem of formwork selection was also explored and was the subject matter of research ran by Orłowski [11], Marcinkowski and Krawczyńska [10], Biruk and Jaśkowski [2] or Ignatowski [6]. The factors affecting the selection of formwork system, proposed by Hanna, Sanvido et. al [4,5] and later applied by numerous researchers, such as Kamarthi [8], Elbeltagi [3] or Kang [9], are classified as follows: building design factors (eg. building shape, slab type), job specification (concrete finish requirements, required speed of construction, floor cycle or rate of casting), local conditions (area practice, weather conditions, site size and location), organizational issues (home office support, hoisting equipment required, safety management, cost and potential re-use of formwork). Those factors have been often used to create knowledge-based decision supporting systems, such as for example: expert system Neuroslab by Hanna [4], Neuroform [8] by Kamarthi, fuzzy logic system by Elbeltagi [3], probabilistic neural network system by Tam [16].

All those systems support the choice of formwork technology (eg. girder or table slab formwork to perform slabs), but does always not provide exact system or producer selection. What's more, although the literature on the subject matter, both foreign and national, suggest various decisive criteria for formwork selection, their importance in the selection problem has not been distinctly formulated. Furthermore - it cannot be formulated without investigation on local contractors' needs or preferences, understanding the building culture and work conditions. Therefore, author ran a structured interview to recognize possible decisive criteria in formwork selection problem. The poll's questionnaire was send to over 100 various contractors with different experience in building performance (from under 10 years to over 25 years of experience) and different level of employment (from under 50 workers to over 100 employees). 
The interviewees were asked:

- if they use their own formwork, rent it, or both - use own and leased formwork to perform building works;

- what types of formwork and formwork systems they usually use, which are known to them;

- have they ever selected formwork from several types, systems or producers;

- which criteria they consider during formwork selection or which they would consider if it was possible or if they were asked to;

- would they use any decision-supporting system if it was possible.

To recognize contractors' preferences for formwork selection and their hierarchy in the selection problem, 9 preferentially independent decisive criteria had been formulated:

- criterion no 1: formwork ergonomics, which stands for easy and fast assembly, lightweight elements for manual assembly, possibility of moving complete sets of formwork, etc.

- criterion no 2: support from the formwork supplier, including formwork design, staff training, trial assembly of more complicated elements, etc.;

- criterion no 3: formwork versatility, which means that formwork can be used to form construction elements of various type, shape, location, etc.,

- criterion no 4: quality of concrete surface and concrete performance;

- criterion no 5: safety, which means that formwork is equipped with platforms and provides high safety for the construction team;

- criterion no 6: durability of formwork elements;

- criterion no 7: formwork known to workers - was used, is adapted to the staff abilities, workers don't need special training;

- criterion no 8: compatibility with yet owned formwork system (or elements);

- criterion no 9: attractive lease terms.

The polls' questionnaire enabled the responders (in one open question) to suggest their own criteria, important to them when choosing the formwork system and to give their own remarks on the problem. All the suggested criteria were rated by the interviewees from 1 to 5 , where mark 1 stood for „,no important”, 2 - ,little important”, 3 - ,,averagely important”, 4 - ,,important” and 5 - ,very important”. The response level of the survey made it possible to identify contractors' preferences when selecting formwork in order to aid the selection process with an MCDA method that involves criteria weights. 


\section{DECISIVE CRITERIA ANALYSIS}

\subsection{PoOls ANALYSIS}

Having polls analyzed, it can be unambiguously said, that Polish contractors willingly use leased formwork in concrete works performance. Over 94\% responders answered that he used "only leased" (41,2\%) and "both, own and leased" (53\% interviewees) formwork. This obviously arises from high costs of purchasing new formwork elements as well as contractors' concerns about having the potential of purchased formwork untapped or unemployed. Only 5,9\% contractors own enough formwork elements to perform construction works without extra formwork rental. The described above structure of formwork possession is shown on Fig. 1, while Fig.2 and Fig. 3 present the relationship between the type of formwork possession vs contractor's level of employment (Fig. 2) and experience gained in work performance (Fig. 3).

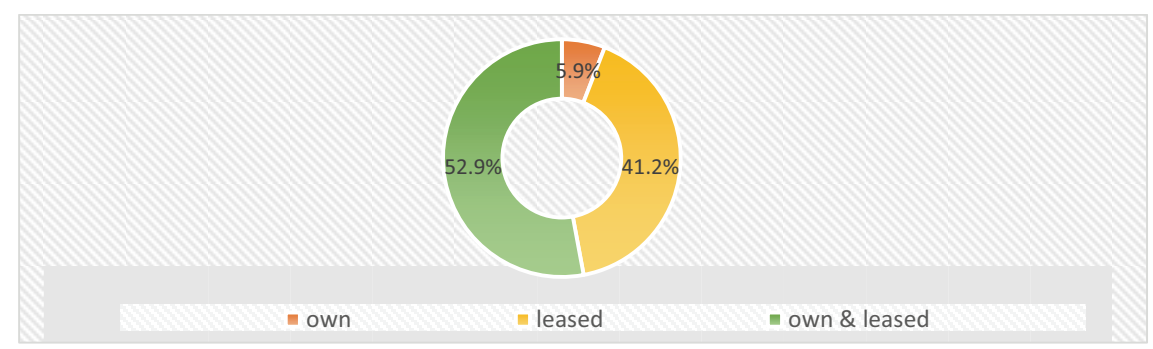

Fig. 1. Structure of formwork possession in concrete works performance

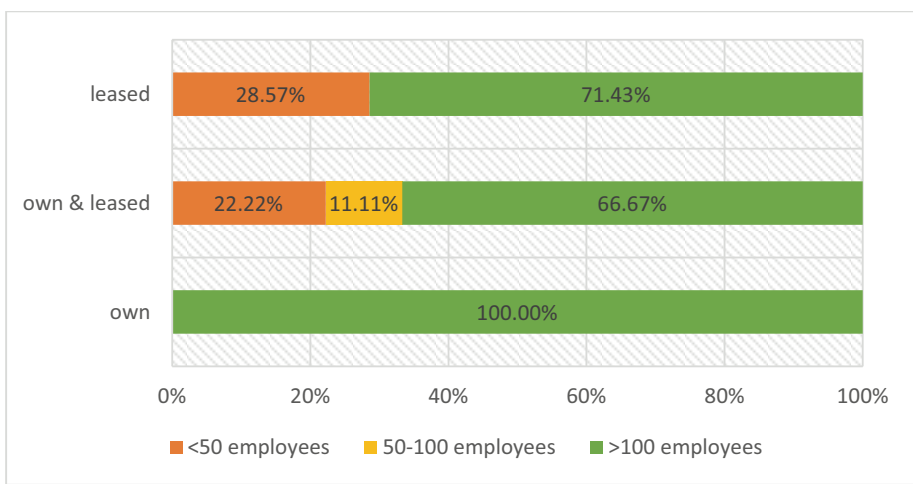

Fig. 2. The type of formwork possession vs contractors' level of employment 
All the interviewed contractors who rent formwork:

- had, at least once, selected formwork from various producers and various systems.

- would be interested in using a decision-supporting system (application) to help or advise in decision making, especially when more than one (price) criterion is considered.

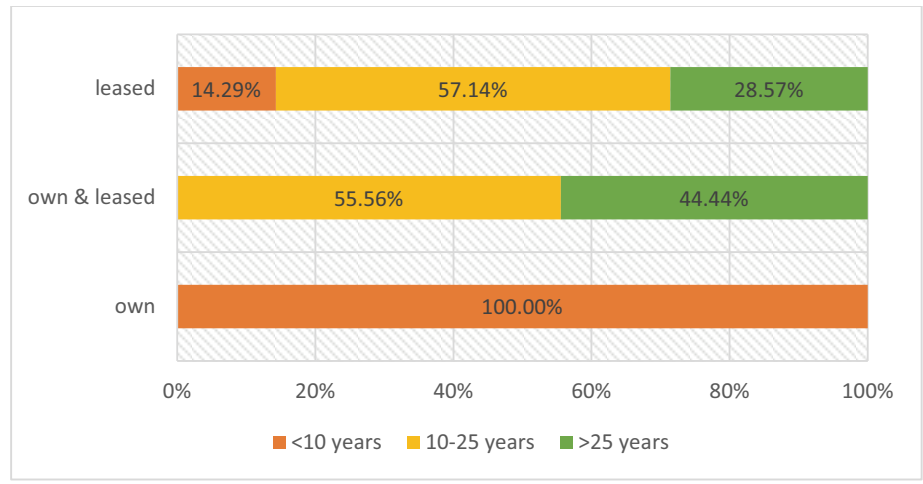

Fig. 3. The type of formwork possession vs contractors' experience in works performance

The goal of the survey was to identify which and how each decisive criteria are important to Polish contractors. The bar graph showing frequency of marks (form 1 to 5) given to each criterion is presented on Fig. 4

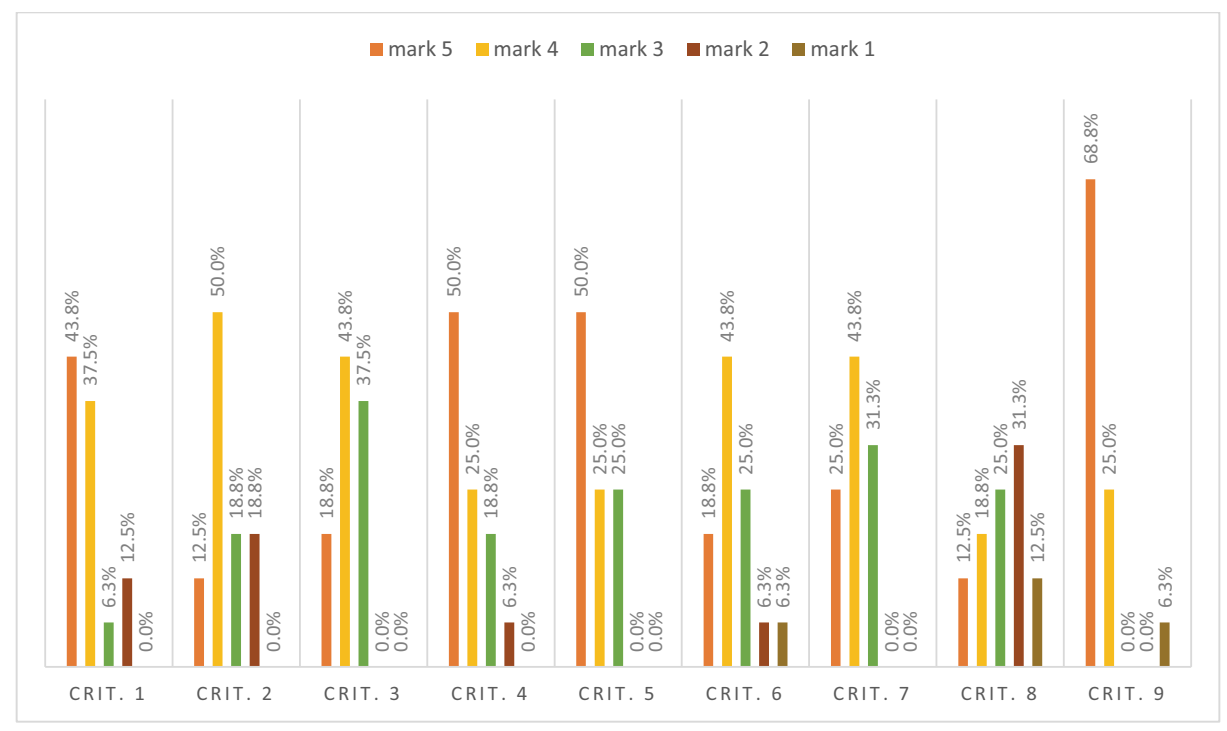

Fig. 4. Frequency of marks given to each criterion 
As we can see, the main factor that affects formwork system selection is criterion no 9 - renting conditions, which include attractive leasing price. It was expected, but fortunately, it is not the only criterion marked as ,,very important”. Over 50\% interviewees gave the highest mark to criterion no 4 and no 5 - quality of works and works safety respectively. Ergonomics was marked with the highest number of $4 \mathrm{~s}$ and $5 \mathrm{~s}$ together (81,3\%). Far more less attention was paid to the compatibility of leased formwork with the owned one. The mean mark for this criterion is, however, within the interquartile range, so there is no reason to reject it. Mean marks for all the criteria are collected in Table 1.

Table 1. Mean values of criteria marks

\begin{tabular}{|c|c|c|c|c|c|c|c|c|c|}
\hline Criterion number & 1 & 2 & 3 & 4 & 5 & 6 & 7 & 8 & 9 \\
\hline Mean mark & 4,13 & 3,56 & 3,81 & 4,19 & 4,25 & 3,63 & 3,94 & 2,88 & 4,73 \\
\hline
\end{tabular}

What is worth mentioning, $39 \%$ of the interviewees gave their own extra remarks. $31 \%$ contractors preferred formwork with uncomplicated accessories and connecting parts (couplers, ties, etc.) and formwork, which can be moved in integrated pieces. For $8 \%$ responders, an important factor was also the possibility of trial formwork assembly done by the supplier, especially in case of complicated concrete structures. All the formwork features given by interviewees fit the basic criteria, proposed in the questionnaire - this is formwork ergonomics and supplier's or producer's support, which only confirms their rightness.

\subsection{CRITERIA ORDERING}

Having decisive criteria stated, we should order them and establish weights, which could be used in a multi-criteria decision analysis procedure. Criteria weight ordering always pays a key role in the multi-criteria decision analysis, regardless of the decision-supporting method, and was a subject of research carried out by Stillwell, Savier and Edwards [15], Barron and Barret [1], Solymosi and Dompi [14], Jia [7] or Roszkowska [13]. From several ordering methods the following should be mentioned: Equal Weights Method (EW), Stillwell's: Reciprocal Ranks Method (RR), Rank Sum Method (RS) and Rank Exponent Weight Method (RE), and Barron's Rank-Order Centroid Weight Method (ROC). Formulas for all the methods are clearly described in [13]. In order to compare and choose the most appropriate weight ordering method, let's follow Table 2 and Fig. 5, where criterions' ranks and weights calculated according to RR, RS, RE, ROC methods are gathered. 
Table 2. Criterion weights obtained with different normalization methods, $n=9$

\begin{tabular}{|c|c|c|c|c|c|c|c|c|}
\hline \multirow{3}{*}{ Criterion } & \multirow{3}{*}{$\begin{array}{l}\text { Mean value } \\
\text { of crit. mark }\end{array}$} & \multirow{3}{*}{$\begin{array}{c}\text { Crit. } \\
\text { rank } \\
r_{k}\end{array}$} & \multicolumn{6}{|c|}{ Criteria weights (weight designation and formula) } \\
\hline & & & $w_{k}(R S)$ & $\begin{array}{c}w_{k}(R E) \\
p=0,20\end{array}$ & $\begin{array}{c}w_{k}(R E) \\
p=0,75\end{array}$ & $\begin{array}{c}w_{k}(R E) \\
p=2,0\end{array}$ & \multirow{2}{*}{$\begin{array}{c}w_{k}(R R) \\
\frac{1 / r_{k}}{\sum_{j=1}^{n} 1 / r_{j}}\end{array}$} & $w_{k}(R O C)$ \\
\hline & & & $\frac{2\left(n+1-r_{k}\right)}{n(n+1)}$ & \multicolumn{3}{|c|}{$\frac{\left(n-r_{k}+1\right)^{p}}{\sum_{j=1}^{n}\left(n-r_{j}+1\right)^{p}}$} & & $\frac{1}{n} \sum_{j=k}^{n} \frac{1}{r_{j}}$ \\
\hline Crit. $1(\mathrm{k}=1)$ & 4,13 & 4 & 0,133 & 0,119 & 0,131 & 0,126 & 0,088 & 0,111 \\
\hline Crit.2 (k=2) & 3,56 & 8 & 0,044 & 0,095 & 0,058 & 0,014 & 0,044 & 0,026 \\
\hline Crit.3 $(\mathrm{k}=3)$ & 3,81 & 6 & 0,089 & 0,109 & 0,097 & 0,056 & 0,059 & 0,061 \\
\hline Crit.4 $(k=4)$ & 4,19 & 3 & 0,156 & 0,122 & 0,147 & 0,172 & 0,118 & 0,148 \\
\hline Crit.5 (k=5) & 4,25 & 2 & 0,178 & 0,126 & 0,163 & 0,225 & 0,177 & 0,203 \\
\hline Crit.6 ( $\mathrm{k}=6)$ & 3,63 & 7 & 0,067 & 0,103 & 0,078 & 0,032 & 0,050 & 0,042 \\
\hline Crit.7 (k=7) & 3,94 & 5 & 0,111 & 0,114 & 0,114 & 0,088 & 0,071 & 0,083 \\
\hline Crit. $8(\mathrm{k}=8)$ & 2,88 & 9 & 0,022 & 0,083 & 0,034 & 0,004 & 0,039 & 0,012 \\
\hline Crit.9 $(\mathrm{k}=9)$ & 4,73 & 1 & 0,200 & 0,129 & 0,178 & 0,284 & 0,353 & 0,314 \\
\hline
\end{tabular}

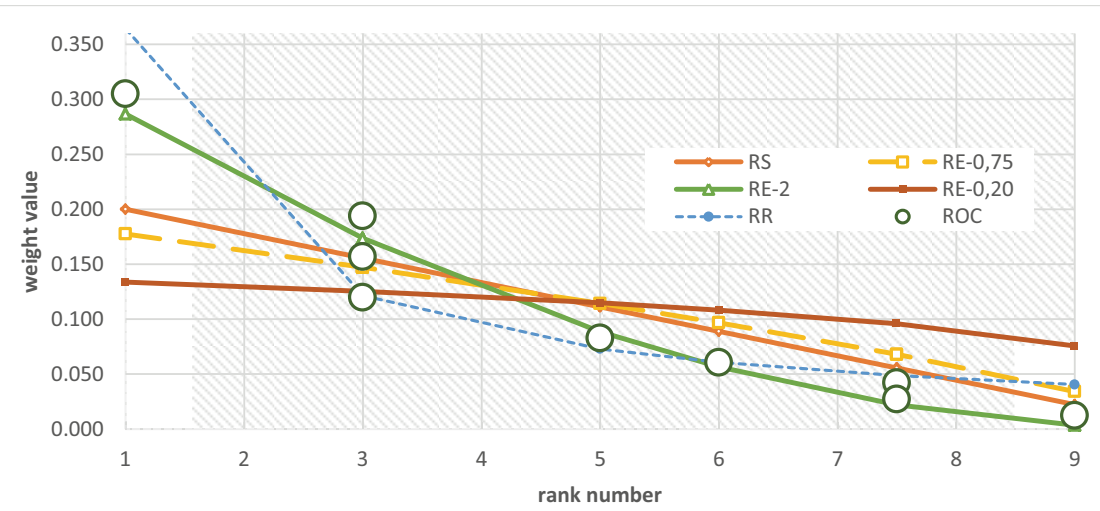

Fig. 5. Criteria weights and their steepness obtained within different methods

Weight determination strongly influences the final result of decision making. A choice between methods depends basically on the steepness of the true weights. The centroid (ROC) weights are steep and assign greater weight to the most important criteria, while rank sum (RS) weights are flatter and linear from the most to the least important, which seems to be too ideal. The reciprocal (RR) weights descend aggressively after the most important rank, but for the least important are 
higher than ROC weights. The ordering procedure that is, in author's opinion, the most valuable for the discussed problem is rank exponent method, which enables the planner to adjust steepness of weights by changing parameter $p$. In other methods, only the rank number determines the weight, which means that for two different decision problems with the same number of criteria, weights will be the same. Therefore, it has been decided to use RE method to order the decisive criteria, which, in further research, will be applied in MCDA methods in formwork selection problem. To order finally the decisive criteria, criteria no: 1,5 and 4, as well as no 2 and 6 are given the same rank, due to similar criterion mark. The best fitting curve that approximates steepness of criteria grading diversity can be obtained within parameter $p=0.26$, which is shown on Fig. 6 . The fitting accuracy is about $97,37 \%$.

Table 3. Final criteria weights for formwork selection problem

\begin{tabular}{|c|c|c|c|}
\hline Criterion & Mean value of criterion mark & Criterion rank, $\boldsymbol{r}_{\boldsymbol{k}}$ & Criterion weight $\boldsymbol{w}_{\boldsymbol{k}}(\boldsymbol{R E}, \boldsymbol{p}=\mathbf{0 , 2 6})$ \\
\hline Crit. 9 & 4,73 & 1 & 0,134 \\
\hline Crit. 5 & 4,25 & 3 & 0,125 \\
\hline Crit. 4 & 4,19 & 3 & 0,125 \\
\hline Crit. 1 & 4,13 & 3 & 0,125 \\
\hline Crit. 7 & 3,94 & 5 & 0,115 \\
\hline Crit. 3 & 3,81 & 6 & 0,108 \\
\hline Crit. 6 & 3,63 & 7,5 & 0,096 \\
\hline Crit. 2 & 3,56 & 7,5 & 0,096 \\
\hline Crit. 8 & 2,88 & 9 & 0,076 \\
\hline
\end{tabular}

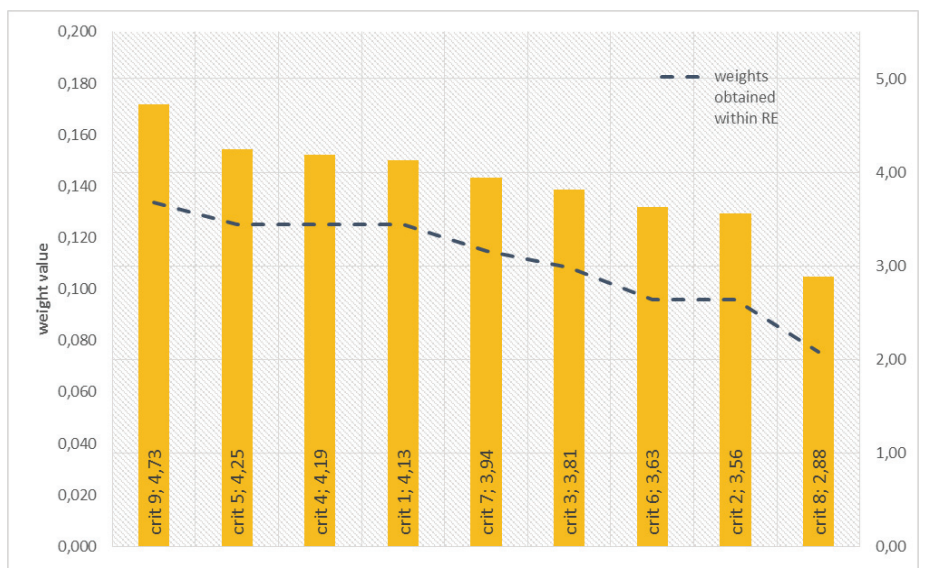

Fig. 6. Criteria weights obtained with RE method vs criteria mean marks 
The rank sum method describes the steepness of interviewees' preferences quite well - it does not overemphasize the price criterion no 9 as well as does not undervalue those criteria which are little less important for the contractors (crit. no 2 and no 6).

\section{CONCLUSIONS}

The problem of formwork selection is one of the key issues of concrete works planning, particularly, when the leased formwork is employed to complete concrete works, what is common practice in modern building performance. The goal of the paper was to discuss the factors that can influence the choice of formwork system and their importance in selection process. Basing on results of the polls conducted among Polish contractors, it was possible to confirm 9 decisive criteria, including leasing conditions, safety of works, quality of concrete surface and ergonomics of formwork system. All the criteria were ordered using different ordering methods, however the Rank Exponent method proved to be the most valuable one, as it did not overvalue the most important criteria and underrate the least one. The obtained weights can be applied to solve formwork selection problem using various MCDA methods (eg. SAW, TOPSIS, fuzzy TOPSIS etc.), which is the subject matter of other author's paper [17]. Please, however, keep in mind, that the weights calculated from polls' results are not the only right and finally determined ones for the formwork selection problem - they should be verified every time by the planner, who can adapt them to individual site conditions.

\section{REFERENCES}

1. F.H. Barron, B.E. Barret, "Decision quality using ranked attribute weights", Management Science 42, 1996, pp. $1515-1523$

2. S. Biruk, P. Jaśkowski, „Dobór elementów deskowania ścian z uwzględnieniem kryteriów ekonomicznych”, Budownictwo i Architektura 12 (1), 2013, pp. 7-14

3. E. Elbeltagi et al., "Selection of slab formwork system using fuzzy logic", Construction Management and Economics 29, 2011, pp. 659-670

4. A.S. Hanna, V.E. Sanvido, "Interactive vertical formwork selection system", Concrete International 12(4), 1990, pp. 26-32

5. A.S. Hanna, J.H. Willenbrock, V.E. Sanvido, "Knowledge acquisition and development for formwork selection system", Journal of Construction Engineering and Management 118(1), 1992, pp. 179-198

6. P. Ignatowski, „Deskowania. Najczęstsze błędy przy ich doborze”, Inżynier Budownictwa 10, 2011, pp. 82-96.

7. J. Jia, G. Fischer, J.S. Dyer, "Attribute weighting methods and decision quality in the presence of sampling error: a simulation study”. Journal of Behavioral Decision Making 11(2), 1998, pp. 85-105

8. S.V. Kamarthi, V.E. Sanvido, S.R. Kumara, "Neuroform - neural network system for vertical formwork selection”, Computing in Civil Engineering 6(2), 1992, pp. 178-193

9. K.I. Kang et al., "Decision support model using the AdaBoost algorithm t select formwork systems in high-rise building construction", 25th ISARC-2008 Proceedings, 2008 
10. R. Marcinkowski, A. Krawczyńska, „Wybór systemu i planowanie wykorzystania deskowań w wykonawstwie monolitycznych konstrukcji betonowych", Przegląd Budowalny 3, 2009, pp. 53-59

11. Z. Orłowski, T. Wrzos, K. Turczyniak, „Optymalizacja doboru deskowań ramowych ściennych”, Inżynier Budownictwa 5, 2013, pp. 67-71

12. D.G. Proverbs, G.D. Holt, P.O. Olomolaiye, "Construction resource/ method factors influencing productivity for high rise concrete construction", Construction Management and Economics 17, 1999, pp. 577-587.

13. E. Roszkowska, "Rank ordering criteria weighting methods - a comparative overview", Optimum. Studia Ekonomiczne 5(65), 2013, pp.14-31

14. T. Solymosi, J. Dompi, "Method for determining the weights of criteria: the centralized weights", European Journal of Operational Research 26, 1986, pp. 35-41

15. W. Stillwell, D.A. Seaver, W. Edwards, "A comparison of weight approximation techniques in multi-attribute utility decision-making", Organizational Behavior and Human Performance 28, 1986, pp. 62-77

16. C.M. Tam et al., "Selection of vertical formwork system by probabilistic neural networks model", Management and Economics 23, 2005, pp. 245-254

17. A. Krawczyńska-Piechna, "Application of TOPSIS method for formwork selection problem", Applied Mechanics and Materials, in print

\section{LIST OF FIGURES AND TABLES:}

Fig. 1. Structure of formwork possession in concrete works performance

Rys. 1. Struktura własnościowa deskowań systemowych w trakcie realizacji robot betonowych

Fig. 2. The type of formwork possession vs contractors' level of employment

Rys. 2. Forma własności deskowania a wielkość zatrudnienia wykonawcy

Fig. 3. The type of formwork possession vs contractors' experience in works performance

Rys. 3. Forma własności deskowania a doświadczenie wykonawcy w realizacji robót

Fig. 4. Frequency of marks given to each criterion

Rys. 4. Rozkład częstości ocen poszczególnych przyznawanych poszczególnym kryteriom

Fig. 5. Criteria weights and their steepness obtained within different methods

Rys. 5. Wagi kryteriów otrzymanych różnymi metodami i ich zmienność

Fig. 6. Criteria weights obtained with RE method vs criteria mean marks

Rys. 6. Wagi kryteriów otrzymane metodą RE na tle średnich ocen kryteriów

Tab. 1. Mean values of criteria marks

Tab. 1. Wartości średnie ocen kryteriów

Tab. 2. Criteria weights obtained with different normalization methods

Tab. 2. Wagi kryteriów decyzyjnych otrzymane różnymi metodami normalizacji

Tab. 3. Criteria weights for formwork selection problem

Tab. 3. Wagi kryteriów decyzyjnych dla problem wyboru deskowania 


\section{ANALIZA KRYTERIÓW DECYZYJNYCH W PROBLEMIE WYBORU SYSTEMU DESKOWAŃ SYSTEMOWYCH}

Keywords: deskowania systemowe, kryteria decyzyjne, porządkowanie kryteriów

\section{STRESZCZENIE:}

Wybór deskowania do zastosowania w realizacji monolitycznych robót betonowych jest pierwszym problemem, jaki planista rozwiązuje w zakresie planowania organizacji pracy deskowań na budowie. Wybrany system powinien umożliwiać wykonanie wszystkich elementów konstrukcyjnych obiektu, zapewnić sprawny montaż i demontaż deskowania oraz gwarantować bezpieczeństwo pracowników podczas realizacji robót. Nie bez znaczenia są warunki najmu lub zakupu deskowania i współpracy z dostawcą (lub producentem) w zakresie wsparcia wykonawcy na budowie.

Analizując ilość i różnorodność możliwych do rozpatrzenia w procesie decyzyjnym kryteriów, można stwierdzić, w świetle przeprowadzonych studiów literaturowych, że jednoznaczne wskazanie kryteriów i ich istotności przy dokonywaniu wyboru, bez przeprowadzenia badań - nie może być dokonane. Ważna jest również weryfikacja samego podejścia wykonawców do zagadnienia wyboru deskowania i ocena potrzeby opracowania metodyki takiego wyboru.

W celu ustalenia kryteriów decyzyjnych, jakimi kierują się polscy wykonawcy robót, wybierając system szalunkowy do zastosowania w realizacji monolitycznego obiektu betonowego, jak również określenia ich istotności, opracowano i przeprowadzono badanie ankietowe. Formularz ankiety został rozesłany do podmiotów, zajmujących się wykonawstwem konstrukcji obiektów kubaturowych. W badaniu respondenci zostali poproszeni o udzielenie odpowiedzi na pytania:

- jaka jest forma własności stosowanych przez nich deskowań (własne / dzierżawione / własne i dzierżawione),

- jakie rodzaje deskowań stosują najczęściej, jakie rodzaje deskowań są im znane;

- czy wynajmując deskowanie wybierają lub mają/mieli możliwość wyboru systemu spośród kilku systemów / producentów deskowań;

- na jakie kryteria zwracają uwagę przy wyborze deskowania, lub na które by zwracali uwagę, gdyby była taka możliwość;

- czy uważają że warto opracować system wspomagający wybór deskowania i ewentualnie skorzystaliby $\mathrm{z}$ niego.

Kluczowym zagadnieniem ankiety było poznanie preferencji wykonawców przy wyborze systemu szalunkowego. W tym celu sformułowano dziewięć kryteriów decyzyjnych:

- $\quad$ kryterium k1: ergonomiczność systemu szalunkowego;

- $\quad$ kryterium k2: wsparcie wykonawcy ze strony dostawcy bądź producenta deskowania w trakcie realizacji robót;

- $\quad$ kryterium k3: uniwersalność systemu deskowania;

- kryterium k4: jakość wykonania konstrukcji przy użyciu danego systemu deskowania;

- $\quad$ kryterium k5: stopień zapewnienia bezpieczeństwa podczas wykonywania robót;

- $\quad$ kryterium k6: trwałość elementów deskowania;

- $\quad$ kryterium k7: znajomość deskowania przez pracowników;

- kryterium k8: kompatybilność dzierżawionego deskowania z elementami deskowania posiadanymi przez respondenta;

- $\quad$ kryterium k9: korzystne cenowo warunki najmu. 
Ankietowani mogli także zaproponować własne kryteria, istotne z ich punktu widzenia w procesie wyboru deskowania. Wymienione kryteria oceniane były przez respondentów w skali od 1 do 5, gdzie: 1 - oznacza, że kryterium oceniono jako „w ogóle nieistotne w procesie wyboru deskowania”, zaś 5 - „bardzo istotne”.

W pracy zawarto analizę wyników badań ankietowych, na podstawie których można jednoznacznie stwierdzić, że wykonawcy robót $\mathrm{w}$ znacznej mierze korzystają z dzierżawionych deskowań systemowych. $\mathrm{Z}$ ocen dokonanych przez respondentów wynika, że dominującym kryterium decyzyjnym w procesie wyboru systemu szalunkowego jest korzystny koszt dzierżawy deskowania. Nie jest to jednak jedyne, oceniane jako „bardzo istotne”, kryterium wyboru szalunku - 50\% ankietowanych najwyżej oceniło także jakość wykonania formowanej konstrukcji oraz stopień zapewnienia przez system deskowania bezpieczeństwa prowadzenia robót. Z kryteriów technologicznych najwięcej ocen „4” i ,5” otrzymało kryterium ergonomiczności szalunku. Znacznie mniej uwagi respondenci przywiązywali do kompatybilności dzierżawionego systemu z posiadanym szalunkiem.

Pozyskane metodą ankietową informacje na temat preferencji wykonawców w procesie wyboru systemu szalunkowego posłużyły do ustalenia hierarchii kryteriów decyzyjnych. Przeanalizowano kilka podstawowych metod normalizacji rang, w tym: metodę równych wag (EW), metody rang odwróconych (RR), znormalizowanej sumy rang (RS), metodę wykładniczą (RE), jak również metodę centroidu (ROC). Dla rozważanego problemu zadecydowano o hierarchizacji kryteriów metodą wykładniczą z parametrem $p=0.26$, co zadowalająco odzwierciedla zróżnicowanie preferencji wykonawców. Zastosowana metoda nie przewartościowuje kryterium cenowego, jak również nie zaniża wagi kryteriów niżej ocenionych przez respondentów.

Ustalone dla kryteriów wagi pozwalają na ich hierarchizację i mogą być wykorzystane w wielu metodach MCDA. Zaproponowane wagi stanowią także punkt wyjścia do interaktywnego planowania robót, w którym planista-decydent rozmywa zakresy wag, dostosowując je do realiów prowadzonej inwestycji. 